\title{
Product export diversification and sustainable economic growth in developing countries
}

\author{
Elodie Mania* and Arsène Rieber* \\ * CREAM, University of Rouen Normandy, France \\ Abstract
}

A consensus on the virtues of an economic development strategy based on export diversification has emerged from the recent economic literature. The purpose of this paper is to revisit that relationship by questioning the sustainability of such a strategy. Drawing on a balance of payments constrained growth model, we compare the re-composition of productive capacities that follows export diversification with the evolution of countries' external constraints. Based on econometric estimates of panel data, the lessons of the model allow us to analyze and compare, over the period 1995-2015, export diversification in three samples of developing countries, namely: Latin America, Sub-Saharan Africa and Developing Asia.

Keywords: BoP constrained growth model, export diversification, sustainable economic growth, developing countries.

JEL Classification: F1, F43, 011, 057 


\section{Introduction}

Major international organizations, led by the International Monetary Fund (IMF), have agreed recently to extol the virtues of an economic development strategy based on export diversification (IMF, 2014a, 2014b). For a developing economy, it is argued, export diversification makes it possible to stabilize export earnings in the face of price volatility in international markets and acts as a driver of economic growth through the technology spillovers from which other sectors benefit (Amin Gutiérrez de Piñeres and Ferrantino, 2000; Lederman and Maloney, 2012). This consensus has two main sources. The first is the successful experience of the Asian NICs' industrialization (World Bank, 1993). Since the end of the 1970s and in a global context of trade liberalization, these countries have adopted pro-active policies for export promotion based on the structural transformation of their economies, including export diversification. The second source of this new consensus on the virtues of export diversification is an empirical study by Imbs and Wacziarg (2003). In an international cross-sectional study, they identify a U-shaped linkage between per capita income and the degree of production concentration. Subsequently, observation of the quadratic relationship has been extended to the relationship between export diversification and level of development (Klinger and Lederman, 2006; Parteka, 2007;

Easterly, Reshef and Schwenkenberg, 2009; Cadot et al., 2013): the first stage of economic development is followed by a diversification of exports. These empirical results coincide with the recommendations of the major international institutions.

As far as theory is concerned, the debate is not new and was at the center of the controversies of the 1950 s between free-trade and structuralist economists. Since Ricardo (1817), the former had been inspired by traditional theories of international trade and preached free trade and specialization based on a country's comparative advantages. Initiated by Krugman (1979), the new theories of international trade update this debate by considering the increasing returns to scale. They show that concentration of a country's exports is a source of gains when the economy is opened up to international trade. Furthermore, Prebisch (1950) and Singer's (1950) works inspired the pioneers of development economics. The latter argue that the comparative advantage thesis inevitably led developing countries to an "immiserizing" growth. For these economists, the differences in economic structures between countries produce a commercial exchange configuration in which industrialized countries export high value-added industrial products and developing countries export primary or labor-intensive goods. However, developing countries' exports are characterized by relatively low levels of income elasticity, low productivity and strong price fluctuations. The volatility of export earnings and the deterioration of the terms of trade condemn developing economies to an "immiserizing" growth. The recommended remedy is export diversification, on the grounds that it reduces an economy's vulnerability to external demand shocks and is conducive to the technological spillovers that are essential for economic takeoff. The contemporary structuralist school subsequently revived the argument against the comparative advantages theory: the process of structural change in a developing economy is driven by the diversification and composition of its exports (Vera, 2006; Botta, 2010; Cimoli et al., 2010; Cimoli et al., 2011). Consequently, development policies need to introduce distortions into the specialization mechanisms of comparative advantages theory (Lederman and Maloney, 2012). To support their theoretical arguments, several authors note that the NICs of Asia and China became industrialized by defying their comparative advantages and diversifying their export structure (Amsden, 1989; Wade, 1990; Lin and Chang, 2009; Rodrik, 2012). More recently, there has been a theoretical convergence, with new versions of mainstream models also introducing export diversification as a factor in economic growth. Based on an extension of Krugman's 1979 model, these models, called "new new trade theory", introduce heterogeneity in productivity between firms into the international trade models (Melitz, 2003; Chaney, 2008; Feenstra and Kee, 2008). They show that a reduction in trade costs increases the number of exporting firms. Since in monopolistic competition each firm produces a 
variety of different goods, the decrease in trade costs will lead to increasing export diversification. Through a selection effect, the reallocation of market shares to the most productive firms then contributes to an increase in productivity at the aggregate level. It can be shown from these models that an economy's export diversification resulting from trade intensification drives economic growth. However, a division remains between neo-structuralist economists and mainstream economists. For the former, export diversification requires active state intervention, whereas for the latter, it is naturally associated with a reduction in trade costs. Apart from this important economic policy controversy, a consensus has been reached around the notion that export diversification contributes positively to economic growth and development.

This argument has been corroborated by many studies on various samples of developing countries and seems empirically very robust. For developing countries, a first set of studies focused on the harm caused by an exclusive specialization in primary goods: the "natural resource curse". The arguments tested draw on Prebisch's thesis (Prebisch, 1959) of a decline in the terms of trade between industrialized and non-industrialized countries, volatile export earnings and low productivity (Sachs and Warner, 1997; Auty, 2000, 2001; Collier and Dehn, 2001). Other studies directly test the relationship between export diversification and economic growth. They show unanimously, from various samples of countries, that export diversification contributes to developing countries' economic growth (Lederman and Maloney, 2006; Agosin, 2007; Naudé and Rossouw, 2011; IMF, 2014a, 2014b, 2017). Recent works improve this result by comparing export diversification with a country's productive structure. The pioneering study by Hausmann et al. (2007) shows that export diversification should be assessed according to the level of sophistication of the exported products: certain products are more promising than others in terms of economic development. Drawing on the capabilities approach, Hidalgo and Hausmann (2009) developed this thesis by comparing product characteristics (product complexity) to country characteristics (country complexity). They show that the complexity of a product is a function of the capabilities it requires. By linking country's export diversification to the complexity of the export baskets, their method makes it possible to assess the complexity of a country's productive structure (Felipe and al., 2012). In addition, Hidalgo et al. (2007) propose the Product Space, a mapping tool that can be used to visualize networks between goods according to the similarity of the capabilities required to produce them. The Product Space differentiates a country's exports on the basis of their ability to facilitate future diversification into higher-productivity products. The merit of this recent literature is that it introduces a qualitative measure into the assessment of the relationship between export diversification and economic development.

However, new firm internationalization strategies are likely to affect the qualitative assessment of the relationship between export diversification and economic growth. In fact, nowadays, the global economy is characterized by a vertical fragmentation of production process, in which countries, particularly developing countries, specialize in specific tasks in a good's production chain. Developing countries integrated into global value chains (GVCs) no longer specialize in the production of a specific good, but in a defined segment of the production process: the operation consists of adding value to a good's production chain (UNCTAD, 2013; Koopman et al., 2014). Thus, many developing economies' export composition integrates this new organization of global production. For these economies, therefore, export diversification is no longer necessarily accompanied by a productive transformation conducive to economic development (Chandra et al., 2007; McMillan and Rodrik, 2011). Indeed, developing countries' integration into GVCs may trap them in the limitations of their comparative advantage as a result of an enforced specialization in low-complexity, labor-intensive tasks with high import content. The benefits of diversification in terms of spillover effects for other productive sectors are thus called into question: export diversification is no more than a reflection of an economy's partial industrialization. In other words, a country's integration into a GVC will admittedly foster rapid 
industrialization accompanied by export diversification but may also lock its economy into "an underindustrialization trap" (Baldwin, 2012). Consequently, export diversification measured by export data does not necessarily reflect the economy's structural transformation and therefore the "qualitative" dimension of its economic growth. In similar terms, Lederman and Maloney (2012) argue that the recent literature findings on Hidalgo and Hausmann's country complexity indicator (2009) can be distorted because these indicators are based on the complexity of exported goods and not on the complexity of the tasks performed. Thus, the measure of complexity of a country's productive structure may be overvalued because of the country's integration into the global value chain through a complex good even though the task actually performed is a low-complexity task. Aware of the problem, International institutions now provide databases on value added that distinguishes foreign value-added from domestic value-added for a country's exports ${ }^{1}$. Unfortunately, these databases provide data over a very limited period and do not allow a product-specific analysis. Consequently, the use of international trade data to analyze export diversification across a large sample of countries is still inevitable.

In comparison to the existing literature, we propose in this paper an alternative methodology that can be used to analyze the quality of exports in terms of productive transformation. In addition, our approach aims to take into account the potential bias introduced by the global fragmentation of the production processes. In this regard, Thirlwall's (1979) law introduces a binding external constraint to growth (the so-called theory of balance-of-payments-constrained growth) and seems to be an approach that is particularly well suited to our purpose. The original intuition of Thirlwall's Law is that an economy's external constraint reflects the quality of its productive structure in the long run. More precisely, in a demand-led growth model, Thirlwall's model (1979) links an economy's structural changes to its external financing constraint by determining a threshold growth rate beyond which growth will be qualified as "non-sustainable" in the long run. Thus, the quality of a country's productive structure can be assessed through the value and evolution of this threshold growth rate. Incorporated into our problematic, this theoretical framework will allow us to compare the structural transformation of productive capacities that accompanies an economy's export diversification with the evolution of the current account balance. For example, a developing economy's integration into GVCs through low-complexity tasks without substantial transformation of the productive structure, such as assembly tasks, will certainly broaden the composition of exports but will be accompanied by a high import content that is potentially unsustainable in the long run. Conversely, integration through complex tasks with a high technological content will relax its external financing constraint as a result of spillover effects on the economy's productive structure. Thus, taking as our starting point an extended version of Thirlwall's law (1979), we begin by proposing a theoretical framework that enables us to identify the required conditions for virtuous export diversification for long-run sustainable growth. We will then use the lessons from our model to analyze, for the period 1995-2015, the impact of export diversification on the sustainable growth of three samples of developing countries, namely: Latin America, Sub-Saharan Africa and Developing Asia. The three regions experienced very contrasting levels and changes in their export composition. Our econometric results will enable us to assess, for each of the three groups, the more or less virtuous nature of these evolutions for the long-run economic growth.

The article is organized as follows. In the second section, we will analyze the evolution of export diversification in the selected developing countries in the three regions. In the third section, we will develop our theoretical model and the estimation issues. Section four will present and analyze the econometric results for our three samples of countries. Finally, the last section will summarize the main conclusions.

\footnotetext{
${ }^{1}$ For example, The World Bank database (World Integrated Trade Solution) or the OECD Trade in Value Added (TiVA) database.
} 


\section{Export diversification in developing countries}

\subsection{Measuring tool}

We chose to measure the diversification level by means of the Theil index (1972), which is undoubtedly one of the most used indexes in the literature on export diversification (Cimoli et al., 2011; Agosin et al., 2012; Cadot et al., 2013; IMF, 2014a, 2014b). The index is proportional to the level of concentration and inversely proportional to the level of export diversification. In terms of index measurement, the greater the scale of disaggregation is, the better the assessment of diversification or concentration will be.

The Theil index has the advantage of disaggregating the degree of diversification into two components: diversification across the extensive margin (namely the between component) and diversification at the intensive margin (the within component). More precisely, a country's export diversification across products can result from the export of new products (diversification at the extensive margin) and from the diversification of exports of existing products, which is reflected in a convergence of the export shares of the goods already exported (diversification at the intensive margins) (Cadot et al., 2011). By construction, the overall Theil index is the sum of the "between" component (or the extensive margin) and the "within" component (or the intensive margin) (see Appendix A). It should be noted that the contribution of the extensive margin to export growth can only be smaller than the contribution of the intensive margin: a new exported good usually accounts for a relatively small share of the export composition and contributes only marginally to export growth. And moreover, in the next period the product is already on the intensive margin (Cadot et al., 2013). Over and above the statistical interpretation, the lesser importance of the extensive margin can also be explained in economic terms. The contribution of the extensive margin requires that the varieties of newly created products are 'sustainable'. Quite logically, therefore, the greater contribution of the intensive margin to export growth is confirmed by numerous econometric studies (Evenett and Venables, 2002; Brenton and Newfarmer, 2007; Amurgo-Pachego and Pierola, 2008).

\subsection{Stylized facts}

The diversification indices are calculated from CEPII's BACl database, which is drawn from the COMTRADE database and provides annual bilateral trade flows of more than 200 countries, covering the period 1995-2015. The goods exchanged are entered under the HS6 nomenclature, with a 6-digit degree of disaggregation (more than 5000 products). The extreme disaggregation makes it possible to obtain a more accurate and precise measurement of diversification. In order to investigate the impact of export diversification on sustainable growth over the period 1995-2015, 54 developing countries are selected from three regions: Latin America (LA), Sub-Saharan Africa (SSA) and developing Asia (DA) (see Appendix B). Our geographical division is justified by the observation that the three regions have their own characteristics: over the last two decades, developing Asian countries have experienced rapid export-driven growth, the Latin America region includes mostly middle-income countries and the SSA area includes most of the low-income economies, dependent on a small range of traditional commodities (Bosker and Garretsen, 2012).

Examination of the evolution of export diversification across products at regional level shows that the three developing areas have very different export structures (Figure 1). Developing Asian countries have the highest level of export diversification in the three zones. In addition, it has been rising steadily over the past 20 years, although the level of increase has been low. In fact, this evolution conceals 
heterogeneity of trajectories between countries, which can be divided into two groups. One is made up of the most advanced countries in the zone, such as China, India and Malaysia, which have embarked on a process of re-concentrating their exports. The other includes "latecomer" countries, such as Vietnam, Laos and Cambodia, which are in a phase of accelerated export diversification (Mathai et al., 2016) (see Appendix C, Figure 4). Latin American countries exports are, on average, relatively less diversified with a slight increase in concentration over a large part of the period for many countries. Colombia, Argentina, Brazil and, more importantly, Venezuela have followed this trajectory (IMF, 2017). Conversely, exports from Sub-Saharan African countries are the most concentrated and the increase in the index shows an intensification of concentration throughout the period, as in the case of the major countries of the zone such as Angola, Nigeria, Republic of the Congo and Ghana (see Appendix C, Figure 4).

Figure 1: Export diversification by region over time (1995-2015)

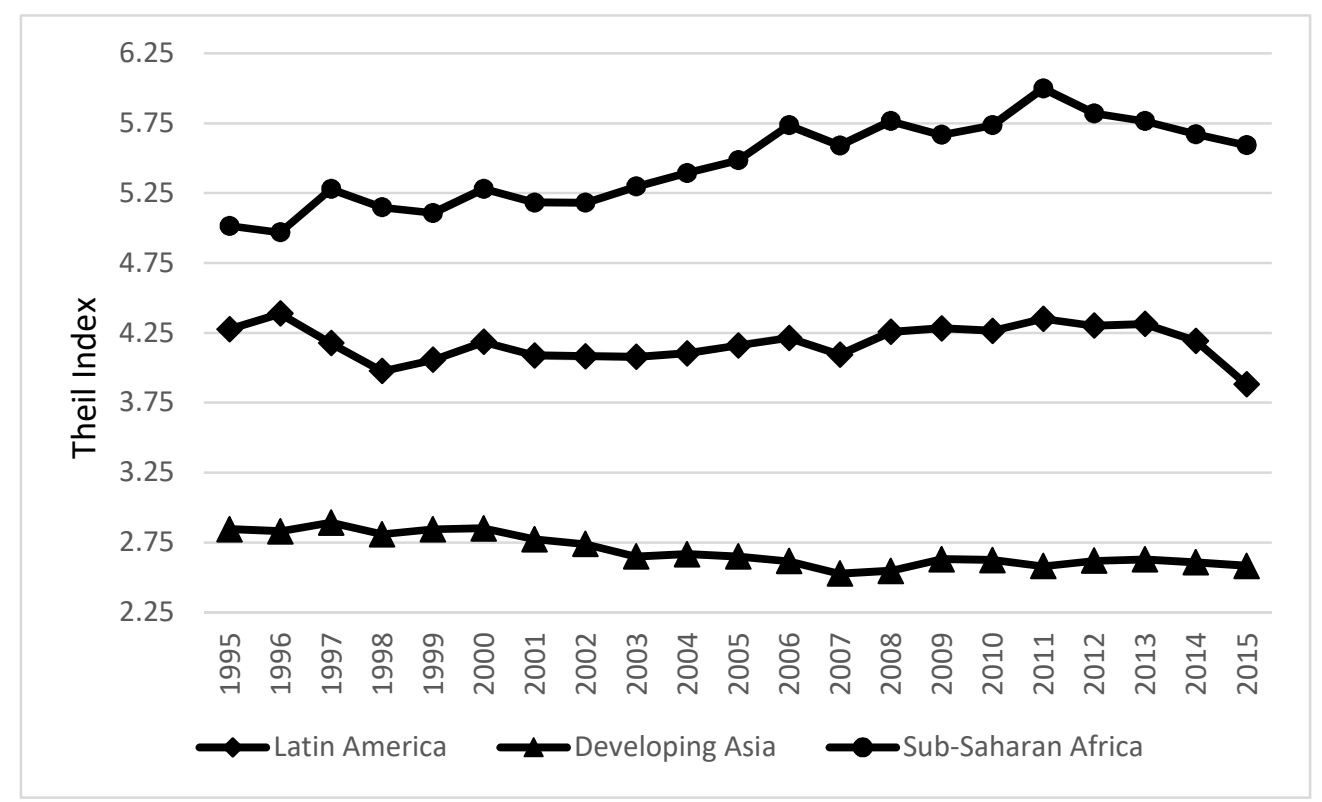

Source: Weighted average, author's calculations from BACl database, 2017.

Now, for each region, we can describe more precisely how export structures have evolved by looking more closely at the decomposition of export diversification at the extensive and intensive margins. Figure 2 shows the average extensive and intensive levels of countries' Theil indices in the 3 regions at the beginning and end of the period. 
Figure 2 : Extensive vs. intensive margins in 1995 and 2015

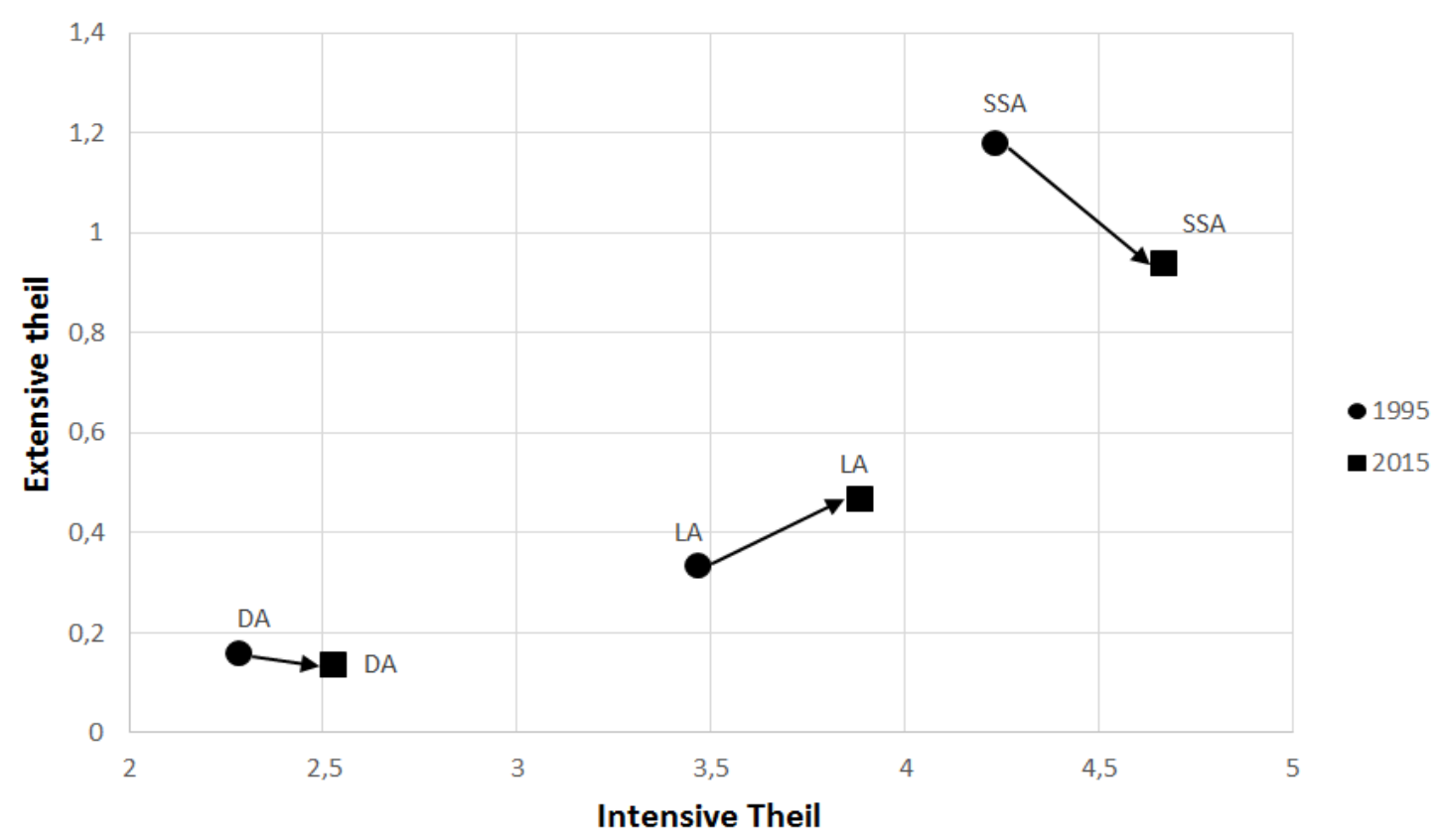

Source: Weighted average, author's calculations from BACl database, 2017.

First of all, Figure 2 supports the previous observation: over the period 1995-2015, the DA region, located in the South-West zone of the figure, is the most diversified, followed by the LA region; the SSA region is the most concentrated.

Developing Asia's economies achieved spectacular export performance and became tremendous international competitors by transforming their export structure jointly across extensive margin diversification and intensive margin concentration. In order to understand these two contrary trends, it should be noted that in this region, unlike in the others, there is a great heterogeneity of trajectories that can be analyzed by attributing the evolution of the intensive margin to advanced countries (China, India, Thailand and Malaysia) and the evolution of the extensive margin to the latecomers (Vietnam, Cambodia or Laos) (see Appendix C, Figure 5). These two trends are in fact complementary: the decrease in the intensive margin reflects the fact that the region's most advanced countries concentrated their exports around more sophisticated existing products while at the same time ceding their labor-intensive activities to the latecomers, thereby enabling the latter to diversify their exports at the extensive margin (Papageorgiou and Spatafora, 2012; ADB, 2014). For example, the Chinese export growth is mainly explained by the change in the intensive margin (Amiti and Freund, 2010). More precisely, for the last decade the country has been moving up the value chain, abandoning the labor-intensive sectors (where they have a comparative disadvantage because of rising wages) in favor of sectors with higher value-added. This evolution has benefitted China's less advanced neighboring countries (Cambodia, Laos, Myanmar and especially Vietnam), which are very strongly open to international trade and have taken over these export sectors, which produce goods that are laborintensive or form part of a low value-added regional assembly process (Mathai et al., 2016). Indeed, compared to the rest of the world, latecomers are today the countries most strongly integrated into the GVC. For example, according to the OECD Trade in Value Added (TiVA) database, Cambodia's GVC participation index is $\mathbf{4 5 \%}$ of its total gross export in $\mathbf{2 0 1 5}$ with an increase in GVC participation of $\mathbf{8 . 4 \%}$ per year over the period 2005-2015. Comparatively, for developing countries, these figures are respectively $41.4 \%$ for the GVC participation index and an annual increase of $6.5 \%$ on average over the period 2005-2015. The example of Vietnam is even more remarkable since nowadays the country is one of the most strongly integrated into the GVC: Vietnam's GVC participation index is 
$55.6 \%$ ( 14 points more than the average for developing countries) with an average increase in GVC participation of $16.4 \%$ per annum over the period 2005-2015 (10 points higher than the average for developing countries). Moreover, the integration of the latecomers into GVCs has led to the export of new goods and therefore to a diversification at the extensive margin, leading in turn to a massive growth in their exports ${ }^{2}$. For example, during the observation period, Vietnam achieved its meteoric diversification with a very high probability of survival for the new varieties by joining GVCs in several product categories through its export of new goods, especially in the electronics sector (IMF, 2014a, 2014b; Mathai et al., 2016) (see Extensive Margin of Developing Asia in Appendix C, Figure 5). However, while the latecomers' integration into GVCs has enabled them rapidly to diversify their exports at the extensive margin, these new exports have a high import content, which is characteristic of specialization in assembly and finishing activities. Ultimately, the joint evolution of the extensive and intensive margins of exports for the DA countries characterizes the GVCs in the region: the region's more advanced countries have refocused their activities by abandoning the labor-intensive sectors (concentration at the intensive margin) to the region's least developed countries, which have thus been able to diversify their trade through the extensive margin.

For the SSA, concentration at the intensive margin can be observed during the observation period, accompanied by a diversification at the extensive margin. The export-led growth boom in Asian countries contributed to a massive increase in the world demand for inputs of primary products (agricultural and mining). This was a windfall that SSA countries were able to exploit; encouraged by the advantageous trend in commodity prices during the 2000s, they concentrated their exports around primary products (represented by a decrease at the intensive margin in Figure 5 in Appendix C). Thus, the pattern of trade between developing Asian countries and SSA, which saw a 40-fold increase in volume over the period 1995-2015, reflects the traditional pattern of international specialization: the African continent imports a wide range of manufactured goods from Asia in exchange for primary products or products based on natural resources (Chen and Nord, 2017). As a result, countries in the sub-Saharan region remain the least specialized in manufactured goods (IMF, 2015). Thus, since the countries of the region have a very limited basket of export products, any attempt at diversification is made at the extensive margin.

Similarly, in the LA region, the rise in world demand for primary products (particularly from Asia) and the soaring prices for these products led to a refocusing of Latin America's exports on raw materials. At the same time, the countries experienced strong competition from Asian manufactured goods, which severely undermined their exports in these sectors (IMF, 2017). This combination of supply (Asian competition) and demand (rising global demand for primary products) shocks explains the joint concentrations at the intensive and extensive margins in the LA region (De la Torre et al., 2015). The growth in exports of Chinese manufactures characterized by strong price competitiveness negatively affected Latin American exports, from Honduras and Mexico, for example. At the same time, the growth in Chinese imports of agricultural and mining products strongly boosted exports of agricultural products from other countries in the region (Paraguay, Argentina and Brazil) as well as mining products (Brazil, Peru and Venezuela) (Artuç et al., 2015).

In order to put these facts into perspective, we present in the following section a theoretical framework that can be used to assess the impact of these changes in export composition on the productive structure of each of these regions.

\footnotetext{
${ }^{2}$ This observation is specific to the latecomers in our DA sample. As one of the referees has emphasized, the integration of a developing country into GVC is not necessarily accompanied by diversification at the extensive margin. The involvement of a country in the GVC can very well lead to diversification at the intensive margin if sectors already exist, and even more to a concentration of exports if sectors capture the resources and the domestic factors initially allocated to other export sectors.
} 


\section{Balance of payments constrained growth theory and export diversification}

\subsection{The theoretical framework}

The Balance of Payments (BoP) constrained growth model rewrites both the Keynesian precepts of demand-led growth and the teachings from structuralist economists about the interaction between economic development and structural changes in an economy's productive capacities. The original insight of Thirlwall's (1979) law is that an economy's external constraint reflects the quality of its productive structure in the long run. In our paper, we propose to amend Thirlwall's (1979) canonical model. Our purpose is to analyze the impact of export diversification on a developing economy's longrun sustainable growth path: the criterion of sustainability refers to a non-explosive external debt on the stationary growth path.

We take the traditional export function as a starting point, where the economy's price competitiveness and the level of world demand determines the economy's export volume:

$$
X=\left(\frac{P_{d}}{P_{f}}\right)^{\phi} Z^{\varepsilon}
$$

where $X$ is the volume of exports; $P_{d} / P_{f}$ is the relative domestic and foreign prices measured in a common currency; $Z$ is the level of world income; $\phi(<0)$ is the price elasticity of demand for exports; $\varepsilon(>0)$ is the income elasticity of demand for exports.

We make an initial modification to Thirlwall's model. We consider that the level of an economy's export diversification affects the income elasticity of exports by modifying the country's productive structure. This effect captures the impact on export performance of the structural changes induced by export diversification. This structural effect is written:

$$
\varepsilon=\varepsilon(D I V) \text { where } \varepsilon^{\prime} \gtreqless 0
$$

Where DIV is the level of export diversification. The sign of the impact of diversification on the income elasticity of exports $\left(\varepsilon^{\prime}\right)$ is a priori indeterminate: according to traditional international trade theories, if the export concentration, in line with comparative advantages, induces structural changes that improve export performance, the sign will be negative; conversely, if export diversification improves export performance, the sign will be positive.

The traditional import function is written:

$$
M=\left(\frac{P_{f}}{P_{d}}\right)^{\psi} Y^{\pi}
$$

where $M$ is the volume of imports; $Y$, the domestic income; $\psi(<0)$, the price elasticity of imports; $\pi(>0)$ the income elasticity of imports.

A second modification we bring to Thirlwall's (1979) model is to consider that an economy's export diversification, by modifying the country's productive structure, is likely to change its income elasticity of imports. The argument is twofold:

- on the one hand, export diversification may be a substitute for imports, in which case an increase in export diversification will be accompanied by a decrease in the income elasticity of imports;

- on the other hand, export diversification may be characterized by a high import content, hence increasing the country's "appetite for imports".

Viewed alongside each other, these two arguments indicate that the impact of export diversification on a country's income elasticity of imports is ambiguous. The structural effect is written:

$$
\pi=\pi(D I V) \text { where } \pi^{\prime} \gtreqless 0
$$


For reasons of analytical convenience, relations (2) and (4) are expressed in linear functional forms:

$$
\begin{aligned}
& \varepsilon=\bar{\varepsilon}+\alpha \text { DIV where } \alpha \gtreqless 0 \\
& \pi=\bar{\pi}+\beta \text { DIV where } \beta \gtreqless 0
\end{aligned}
$$

Taking logs, the export and import functions are written thus:

$$
\begin{aligned}
& \log (X)=\phi \log \left(\frac{P_{d}}{P_{f}}\right)+\bar{\varepsilon} \log (Z)+\alpha D I V \log (Z) \\
& \log (M)=-\psi \log \left(\frac{P_{d}}{P_{f}}\right)+\bar{\pi} \log (Y)+\beta D I V \log (Y)
\end{aligned}
$$

Beside the various elasticities discussed above, the parameters $\alpha$ and $\beta$ capture the interaction effect of diversification on the income elasticities of exports and imports respectively.

Following Thirlwall (1979), the balance of payments equilibrium condition is written:

$$
\boldsymbol{P}_{d} \boldsymbol{X}=\boldsymbol{P}_{\boldsymbol{f}} \boldsymbol{M}
$$

Differentiating equations (5) and (6) with respect to time and incorporating the export and import growth rate expressions in equation (7) in growth rate form, we deduce the income growth rate compatible with the BoP equilibrium:

$$
y_{B o P}=\frac{\left(p_{d}-p_{f}\right)(1+\phi+\psi)+z(\bar{\varepsilon}+\alpha D I V)+\operatorname{div}(\alpha D I V \log (Z)-\beta D I V \log (Y))}{\bar{\pi}+\beta D I V}
$$

where lower-case letters stand for the growth rates of the variables.

\subsubsection{The stationary state and the definition of the long-run sustainable growth path}

To define the long-run sustainable growth path, we refer to Thirlwall's Law (1979), which postulates that an economy cannot finance its growth indefinitely out of a growing inflow of foreign capital, as this will lead to unsustainable foreign debt accumulation. Thirlwall's Law is expressed in these terms: 'In the long run, no country can grow faster than the rate consistent with the balance of payments equilibrium on the current account unless it can finance an ever growing deficit which, in general, it cannot'. In other words, in the long run, an economy's external debt cannot grow indefinitely and must therefore be stabilized. The need to satisfy the external constraint in the long run sets an upper limit to growth given by $y_{B o P}$. If a country's growth rate is lower than $y_{B o P}$, the country will accumulate trade surpluses and become a net capital exporter. Conversely, if its actual growth exceeds $y_{B o P}$, the current account will deteriorate, and the country will become a net capital importer. However, this cannot continue indefinitely.

Two conditions verified in the long run determine the stationary state of an economy:

- on the one hand, the relative purchasing power parity (RPPP) attains in the long run: $p_{d}-p_{f}=0$; - on the other hand, the export productive structure of our economy is stabilized: $d D I V / d t=0 .{ }^{3}$

From equation (8), we therefore obtain the expression of the growth rate compatible with the equilibrium of the BoP in the stationary state, what we call the long-run sustainable growth rate:

\footnotetext{
${ }^{3}$ Note that within a Ricardian model $a ̀$ la Dornbusch, Fischer and Samuelson (1977), the two conditions defining the stationary state are tautological since by definition $d D I V / d t=-\left(p_{d}-p_{f}\right)$ : an economy's export diversification is determined by its price competitiveness.
} 


$$
y_{s u s t}=\frac{\bar{\varepsilon} z+\alpha z D I V}{\bar{\pi}+\beta D I V}
$$

We recognize the originality of Thirlwall's law (1979) $\left(y_{\text {sust }}=\bar{\varepsilon} z / \bar{\pi}\right)$ which, by studying the impact of international trade on the long-run sustainable economic growth, compares the positive impact of an increase in the income elasticity of exports $(\bar{\varepsilon})$ to the negative impact of an increase in the income elasticity of imports $(\bar{\pi})$. In the post-Keynesian literature, the two elasticities are a function of each economy's specific productive structure. In our augmented version (expression (9)), the same is true for export diversification (DIV), which appears simultaneously in the numerator and the denominator. Thus, the differences in export diversification (DIV) between countries explain their differences in terms of sustainable growth rate.

\subsubsection{The impact of export diversification on the sustainable growth rate}

As already observed, export diversification changes a country's productive structure by simultaneously impacting the income elasticity of exports (measured by the parameter $\alpha$ ) and the income elasticity of imports (measured by the parameter $\beta$ ). The first remark that emerges from the observation of equation (9) is that the impact of export diversification on sustainable economic growth arises from the coexistence of these two effects.

Analytically, the impact of diversification is given by the following expression:

$$
\frac{\partial y_{\text {sust }}}{\partial D I V}=\frac{z(\alpha \bar{\pi}-\beta \bar{\varepsilon})}{(\bar{\pi}+\beta D I V)^{2}}
$$

From this last expression, it appears that the sign of the relation is ambiguous:

$$
\frac{\partial y_{\text {sust }}}{\partial D I V} \gtrless 0 \Leftrightarrow \alpha \bar{\pi} \gtrless \beta \bar{\varepsilon}
$$

For given income elasticity values of imports and exports $(\bar{\varepsilon}, \bar{\pi})$ the sign of the relation will be a function of a relative comparison of the values of $\alpha$ and $\beta$. For example, structural changes that strongly improve export performance (positive and high $\alpha$ ) will increase the probability of a favorable impact of diversification on the long-run sustainable growth. Conversely, an export diversification characterized by a high import content (positive and high $\beta$ ) will have a negative impact on the sustainable growth rate and inversely if export diversification is substituted for imports ( $\beta$ negative). It follows for example that export diversification, while having a positive impact on export performance $(\alpha>0)$, may have a negative impact on sustainable economic growth because of the high import content of the diversification $(\beta>\alpha \bar{\pi} / \bar{\varepsilon})$. In this case, and more generally when the sign of the expression (11) is negative, export diversification is described as "bad" diversification in terms of productive transformation. Conversely, export diversification is described as "good" diversification when it allows the external constraint of the economy to be relaxed by jointly improving export performance and reducing (or curbing the rate of increase of) the appetite for imports $(\beta<\alpha \bar{\pi} / \bar{\varepsilon})$. In that case, the sign of expression (11) will be positive.

The two possible configurations formulated by expression (11) can be represented in a diagram $\left(D I V ; y_{\text {sust }}\right)$ (Figure 3$)$. In Figure $3 a$, the relationship between the sustainable growth rate and the level of diversification is positive $(\alpha \bar{\pi}>\beta \bar{\varepsilon})$. The opposite case is represented in Figure $3 b(\alpha \bar{\pi}<\beta \bar{\varepsilon})$.

In both cases, the expression (9) delimits the sustainable growth zone of an economy according to its level of diversification. Indeed, the curve represents the growth rate of an economy associated with a balanced current account in the long run. Above the curve, growth will be described as unsustainable: it will be accompanied by an increasing external debt. Conversely, below the curve, the economy will accumulate current account surpluses. 


\section{Figure 3: The relationship between export diversification and sustainable growth}

Fig 3a : $\alpha \bar{\pi}>\beta \bar{\varepsilon}$

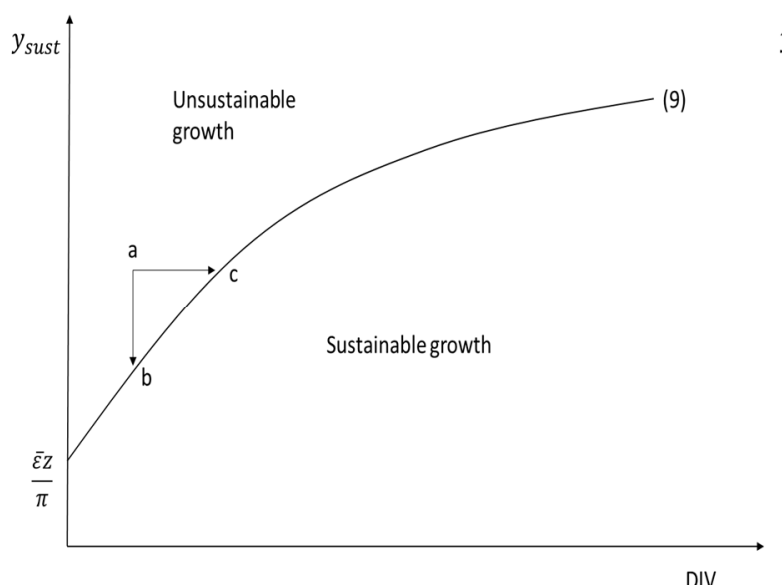

Fig $3 \mathrm{~b}: \alpha \bar{\pi}<\beta \bar{\varepsilon}$

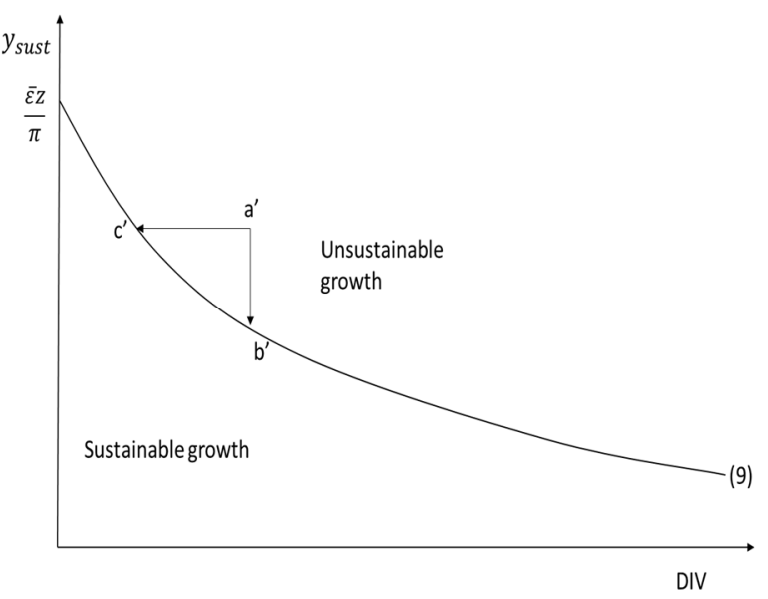

For an economy that is located on a growth path above the long-run sustainable growth rate, the implications in terms of diversification policy are radically different depending on the sign of the relationship. In the case of a positive linkage between diversification and sustainable growth (Figure $3 a$ ), the economy will have two possibilities. It can pursue a recessionary policy in order to restrict the growth of imports and thereby restore the current account balance (shifting from point a to point $b$ ). Conversely, it can diversify its exports while maintaining its productive capacity (shifting from point a to point $\mathrm{c}$ ). In the case of a negative relationship, the recession option is still a solution (moving from point a' to point b'). However, in terms of export diversification, the recommendations are reversed: the economy will have to concentrate its export structure on the most competitive sectors in order to ensure current account equilibrium in the long run (moving from point $a^{\prime}$ to point $c^{\prime}$ ).

\subsection{Estimation issues}

To determine the impact of export diversification on the long-run sustainable growth rate, we need to estimate the parameters $(\alpha, \bar{\pi}, \beta, \bar{\varepsilon})$ that identify the sign of the expression (10). To that end, we will estimate the export and import functions (equations 5 and 6) by making two modifications to their theoretical expression. First, we introduce a time lag on the variable DIV in equations $\left(2^{\prime}\right)$ and $\left(4^{\prime}\right)$ : the argument is that the effects of export diversification on income elasticities $(\varepsilon, \pi)$ are related to structural changes that do not manifest themselves immediately. Second, we assume that it takes time for exports and imports to adjust to the desired level, so that we have a dynamic specification for estimation. The adjustment to the equilibrium specification enables us to distinguish short and longrun elasticities (Santos-Paulino and Thirlwall, 2004). The estimated equations for imports and exports are then:

$$
\begin{aligned}
& \log X_{i t}=a_{1} \log X_{i t-1}+a_{2} \log \left(\frac{P_{d}}{P_{f}}\right)_{i t}+a_{3} \log Z_{i t}+a_{4} D I V_{i t-1} \log Z_{i t}+e_{i t} \\
& \log M_{i t}=b_{1} \log M_{i t-1}+b_{2} \log \left(\frac{P_{d}}{P_{f}}\right)_{i t}+b_{3} \log Y_{i t}+b_{4} D I V_{i t-1} \log Y_{i t}+e_{i t}
\end{aligned}
$$

where $1-a_{1}$ and $1-b_{1}$ are the adjustment coefficients and the other coefficients are the elasticities or the short-run coefficients. Long-run elasticities are obtained by dividing each of the respective coefficients by $\left(1-a_{1}\right)$ for the export function and by $\left(1-b_{1}\right)$ for the import function. For example, 
the short-run income elasticities are $a_{3}$ and $b_{3}$ respectively, while the long-run income elasticities are $a_{3} /\left(1-a_{1}\right)$ and $b_{3} /\left(1-b_{1}\right)$ respectively. Finally, $e_{i t}$ gives the error term.

The variable DIV is the value of the degree of product diversification, as measured by the overall Theil, the extensive Theil and intensive Theil indices. Thus, to analyze the impact of a change in the export structure, each equation comes in three variants.

In order to address endogeneity issues, we use a dynamic panel data model based on the generalized method of moments (GMM) model of Arellano and Bond (1991). The GMM-difference estimator controls for the endogeneity of the explanatory variables where the instruments are based on lagged values of the variables. We compute robust standard errors to solve heteroskedasticity problem.

For our three samples, we estimate the two equations in panel data covering the period 1995-2015. Annual data on exports $(X)$ and imports $(M)$ as well as national income $(Y)$ and foreign income $(Z)$ are at constant 2010 USD and were taken from the World Bank Indicator (WDI) database. The relative price $\left(P_{d} / P_{f}\right)$, defined by the ratio between the domestic price and the foreign price, is approximated by the country GDP deflator divided by the world GDP deflator which are also taken from the WDI database.

\section{Empirical results}

Our estimation results on the import and export equations for the three samples are reported in the appendix ${ }^{4}$ (see Appendix D). Looking first at the price elasticity estimates, we can see that they are relatively weak. For the coefficients of the export functions, the price elasticities are in general significant and have the expected negative sign for DA and LA; they appear to be non-significant for SSA (see Exports in Tables 3, 4 and 5 respectively of Appendix D). For imports, theoretically, we expect a positive sign. This result is observed significantly for LA and SSA coefficients, while DA estimates appear significant but with a negative sign. Although our study of the impact of export diversification on long-run sustainable growth does not involve price elasticities, we note that this "price elasticity pessimism" characterizes developing countries in many econometric studies (Olofin and Babatunde, 2007; Chassem, 2011; Bagnai et al., 2016). It can be learned from these studies that for the import side, the low level of price elasticity or a negative sign reflects developing countries' dependence on imports of capital goods and equipment. For the export side, the non-significant estimates for SSA reflect an export structure based mainly on primary goods, exports of which are not price-sensitive (Baumeister and Peersman, 2013).

Secondly, the short-run income elasticities are very significant and do have the expected positive sign, which enables us to calculate the long-run income elasticity values for our three samples $(\bar{\varepsilon}(\mathrm{LT})$, $\bar{\pi}(\mathrm{LT}))$. The same is true of the long-run coefficients associated with the structural impact of the level of diversification on the income elasticity of imports and exports $(\alpha(\mathrm{LT}), \beta(\mathrm{LT}))($ Table 1$)$.

\footnotetext{
${ }^{4}$ In addition to the GMM estimates, we also run long-run dynamic fixed-effect estimates for robustness checks and found similar results. We do not report the results, but they are available upon request.
} 
Table 1: Effect of export diversification on the long-run sustainable growth rate

\begin{tabular}{|c|c|c|c|c|c|}
\hline & $\begin{array}{c}(1) \\
\bar{\varepsilon}(\mathrm{LT})\end{array}$ & $\begin{array}{c}(2) \\
\bar{\pi}(\mathrm{LT})\end{array}$ & $\begin{array}{c}(3) \\
\alpha(L T)\end{array}$ & $\begin{array}{c}(4) \\
\beta(L T)\end{array}$ & $\begin{array}{c}\text { (5) } \\
\text { Impact }\end{array}$ \\
\hline \multicolumn{6}{|c|}{ Developing Asia } \\
\hline Overall Theil & 3.525 & 1.684 & NS & NS & NS \\
\hline Intensive Theil & 3.110 & 1.388 & 0,017 & NS & + \\
\hline Extensive Theil & 2.875 & 1.590 & $-0,026$ & -0.028 & + \\
\hline \multicolumn{6}{|c|}{ Sub-Saharan Africa } \\
\hline Overall Theil & 1.764 & 1.327 & NS & NS & NS \\
\hline Intensive Theil & 2.085 & 1.172 & NS & NS & NS \\
\hline Extensive Theil & 1.992 & 1.501 & NS & 0.011 & - \\
\hline \multicolumn{6}{|c|}{ Latin America } \\
\hline Overall Theil & 1.761 & 1.159 & NS & 0.005 & - \\
\hline Intensive Theil & 1.785 & 1.156 & NS & 0.005 & - \\
\hline Extensive Theil & 1.669 & 1.226 & -0.012 & NS & - \\
\hline
\end{tabular}

NS: not significant

First, we find that the estimates of the long-run income elasticities of exports $(\bar{\varepsilon}(\mathrm{LT}))$ and imports $(\bar{\pi}(\mathrm{LT}))$ are relatively robust. Their values for the three samples are barely affected by the diversity of the measurements of diversification. The main distinction between the three groups of countries is to be found in the value of the income elasticity of exports (columns (1)). These estimates reflect specific aspects of the international specialization models of our country groups. The DA countries specialize mainly in manufactured goods and their income elasticity of exports is relatively high (between 2.875 and 3.525). Compared to the other two regions, this result confirms the success of their international integration scheme (Diaw et al., 2012; Papageorgiou et al., 2015; Mathai et al., 2016). Conversely, for the LA region and especially for the SSA region, exports of natural resources play a major role in their specialization models (Lederman et al., 2009; Chen and Nord, 2017). However, the literature on growth and structural change points out that such a specialization scheme is weakened by a relatively low level of income elasticity of exports (Dosi et al., 1990). This observation is reinforced by our estimates: for SSA, the value is between 1.764 and 2.085, while for LA it is between 1.669 and 1.785 .

To study the impact of export diversification on sustainable growth in our three country samples, we focus on the structural impact of diversification on income elasticities (of exports and imports respectively) (Table 1, columns (3) and (4)). With reference to our theoretical framework, column (5) calculates the sign of the relation (11) $(\alpha \bar{\pi}-\beta \bar{\varepsilon})$ that summarizes the object of our study, namely the impact of diversification on long-run sustainable growth.

As already noted, the Theil index is proportional to the level of export concentration. Thus, a negative sign of the coefficients associated with the indices shows a positive linkage between export diversification and the dependent variable (and vice versa). For the same reason, the sign of the impact of export diversification on the long-run sustainable growth rate has to be interpreted as the inverse of the theoretical model: a positive sign shows "bad" diversification in terms of productive transformation (and vice-versa).

In our comments on the evolution of the Theil indices in Subsection 2.2., we noted that export diversification trajectories in the DA region are very heterogeneous ${ }^{5}$. This heterogeneity becomes obvious if the evolution of the intensive margin is assigned to the advanced countries of the region

\footnotetext{
${ }^{5}$ Given the heterogeneity of the developing Asian countries in the sample, we integrate a dummy variable that enables us to distinguish the latecomer countries from the advanced countries in the region. To do so, we take as reference Vietnam's GDP per capita in 2015, which is the most advanced among the latecomer countries.
} 
(China, India, Thailand and Malaysia) and that of the extensive margin is assigned to the latecomers (Vietnam, Cambodia, Laos and Myanmar). More precisely, the regionalization of production resulting from GVC integration has been accompanied by a twofold shift: the most advanced countries in the zone have refocused their exports on the more sophisticated existing products (concentration at the intensive margin) while giving up their labor-intensive activities to the latecomer countries, thereby enabling the latter to diversify their exports through the extensive margin. These stylized facts enable us to interpret the export performance of the countries in the region. The results in Table 1 show that the concentration of the most advanced countries in existing exporting sectors (intensive Theil) is associated with an increase in the income elasticity of exports (column (3)) without impacting the income elasticity of imports (column (4)): the marginal effect of a concentration through the intensive margin on the income elasticity of exports is 0,017 . For countries newly integrated into GVCs, the evolution of the export structure has had an impact on export and import competitiveness. As expected, and in line with the stylized facts, diversification into new export sectors (extensive Theil) has a positive impact on the income elasticity of exports (column (3)): the marginal effect is estimated at 0,026 . Moreover, the export of new products is associated with an increase in the income elasticity of imports (column (4)): this increase in the level of diversification leads to a marginal increase in income elasticity of 0.028 points. As a result, the latecomers benefit from the re-concentration of the most advanced countries in the region in terms of export diversification and a structural improvement in their competitiveness. However, the production pattern is characterized by a high import content, which increases their structural dependence on imported inputs ${ }^{6}$.

Overall, the last column of Table 1 shows that for the most advanced countries in the zone (mainly concerned with the intensive Theil), the re-concentration of exports has a favorable impact on the long-run sustainable growth rate. In contrast, for the latecomers, extensive diversification has had a negative effect on the long-run sustainable growth rate because of its high import content. For the latter countries, integration into GVCs has certainly enabled them to diversify their exports rapidly, but it has not been followed by a sufficient modernization of their productive structure, which undermines the long-run sustainability of their growth path. The overall Theil interpretation sums up the two contradictory tendencies within the DA region: the non-significance of the coefficients shows that at the global level, the two opposite evolutions of the two margins are both important in terms of contribution.

For the SSA region, the situation in the various countries with regard to export diversification appears to be relatively more homogeneous. There is a general trend towards export concentration over the whole period caused by the concentration in existing sectors (intensive margin) and accompanied by diversification into new export sectors (extensive margin) (Figure 1 and Figure 2 in Subsection 2.2.). Table 1 shows that a change in the SSA export composition has had no structural impact on export and import performance (columns (3) and (4)). In other words, a change in export composition has had no influence on the long-run sustainable growth rate ${ }^{7}$ (column (5)). The only positive effect is observed at the diversification into new sectors and has reduced the income elasticity of imports (the marginal effect is 0.011 ). Consequently, export diversification at the extensive margin impacts positively the long-run sustainable growth for SSA countries but the effect is too weak for a structural effect at the aggregated scale. Although SSA economies have experienced remarkable economic growth since the early 2000s, our results support the skepticism of some development economists about the structural changes that accompanied it (McMillan et al., 2014). Indeed, diversification into new sectors of primary goods had a structural effect on imports but did not lead to the industrialization of their productive structures.

\footnotetext{
${ }^{6}$ A specific analysis of the case of Vietnam is presented in Bagnai et al. (2015).

${ }^{7}$ From complementary estimations, we verified that the effect of export diversification is limited to a transitory impact on export and import volumes. We show especially that concentration in existing sectors (intensive margin) and diversification in the new sectors (extensive margin) jointly increase export volume. These results are in line with the stylized facts relative to the region's good economic performances since the beginning of the 2000s. We do not report those results, but they are available upon request.
} 
For LA countries, there is a general trend toward export concentration in both existing sectors and new export sectors (Figure 2). In Table 1, we observe that the concentration of exports of existing products (intensive margin) on commodities - fostered by increasing global demand - at the expense of manufactured goods, which are in competition with Chinese exports, has no effect on its export performance but has increased the income elasticity of imports (column (4)): the marginal effect is relatively low (0.005). This result shows that the transformation of the productive structure has increased these countries' dependency on imports of foreign manufactured goods. As far as the external financing constraint is concerned, this change has had a negative impact on long-run sustainable growth (column (5)). At the same time, the narrowing of the export composition of new products (extensive margin) has reduced the income elasticity of exports (column (3)): the marginal effect is estimated at 0.012 . Consequently, concentration in new export sectors has also exerted a negative impact on the long-run sustainable economic growth rate (column (5)).

At the aggregate scale, since the relatively small effect of intensive export concentration is predominant, export concentration has had a low but negative overall impact because of a greater appetite for imports. Thus, for the LA countries, the structural transformation associated with the double export concentration has affected modestly but negatively the growth rate compatible with the BoP equilibrium.

\section{Conclusion}

There is a consensus in the recent economic literature on the virtues of an economic development strategy based on export diversification. Export diversification facilitates structural transformation and is conducive to development and economic growth through cross-sectoral technology spillover effects. The successful experience of the Asian NICs as well as numerous econometric studies show that export diversification contributes positively to economic growth in developing countries. This new consensus confirms the earlier arguments advanced by the pioneers in development (Meier and Seers, 1984). However, not all export baskets have the same potential for growth and economic development. The quality of export diversification must therefore be assessed according to a country's capacity to develop its productive structure. Furthermore, the new firm internationalization strategies may affect the relationship between export diversification and economic growth. Indeed, there is a vertical fragmentation of production process on an international scale, with developing countries specializing in strictly delimited segments of the production processes. GVC integration enables countries to broaden their export composition and rapidly industrialize their economies but does not necessarily lead to transformation of the economic structure favorable to sustainable growth in the long run. To specify the latter concept, we first developed an extended version of Thirlwall's Law in which the criterion of sustainability refers to the external financing constraint, and therefore to the quality of a country's productive structure. The idea is that export diversification, by transforming national productive structure, modifies the export and import structures. The sustainable nature of this restructuring for long-run growth is assessed through the evolution of a country's external constraint. In the second stage of our analysis, we used the lessons from our model to estimate empirically the evolution of the export composition of three samples of developing countries over the period 19952015. For DA countries, our results enabled us to interpret the great heterogeneity of export diversification trajectories within the region. Thus, for the advanced countries of the zone, the strategy of re-concentrating exports on more sophisticated existing products has had a favorable impact on the long-run sustainable growth rate. This result confirms the beneficial nature of the transformation of their productive systems. The integration of latecomer countries into GVCs has enabled these countries to diversify their exports following the abandonment of labor-intensive activities by the most advanced countries in the region. However, the specialization of these countries in new activity segments has not been accompanied by sufficient structural changes, which weakens the sustainability 
of their long-run growth path alarmingly. For SSA countries, our results support the skepticism of some development economists about their remarkable export performance. Our tests show that change in the export composition does not lead to significant changes in their productive structures. The application of our model to LA countries shows that the structural change following the concentration of exports on existing commodities has led to a structural increase in these countries' dependency on imported manufactured goods. According to our results the phenomenon is relatively modest in scale but the tendency towards concentration of the overall export composition affect negatively the longrun sustainable growth path.

\section{References}

Agosin, M. R., Alvarez, R., Bravo-Ortega, C., 2012. Determinants of export diversification around the World: 1962-2000. The World Economy, 35, 295-315.

Agosin, M. R., 2007. Export diversification and growth in emerging economies. Working Paper No.233. Chile: Department of Economics, University of Chile.

Amin Gutiérrez de Piñeres, S., Ferrantino, M. J., 2000. Export dynamics and economic growth in Latin America. Burlington, Vermont: Ashgate Publishing Ltd.

Amiti, M., Freund, C., 2010. The Anatomy of China's export growth, in: R.C. Feenstra and S.-J. Wei, China's Growing Role in World Trade. University of Chicago press, Chicago, 35-56.

Amsden, A. H., 1989. Asia's next giant: South Korea and late industrialization (pp.400). New York, N.Y.: Oxford University Press.

Amurgo-Pacheco, A., Pierola, M.D., 2008. Patterns of export diversification in developing countries: intensive and extensive margins. Policy Research Working Paper No. 4473. The World Bank, Washington, D.C.

Arellano, M., Bond., S., 1991. Some tests of specification for panel data: Monte Carlo evidence and an application to employment equations. The Review of Economic Studies, 58, 277-97.

Artuç, E., Lederman, D., Rojas, D., 2015. The rise of China and labor market adjustments in Latin America. Policy Working Paper No.7155. The World Bank, Washington, D.C.

Asian Development Bank (ADB), 2014. Asian Development Outlook 2014 Update: Asia In Global Value Chains. Mandaluyong City, Philippines: Asian Development Bank.

Auty, R., 2000. How natural resources affect economic development. Development Policy Review, 18, 347-364.

Auty, R., 2001. The political economy of resource-driven growth. European Economic Review, 45, 839846.

Bagnai, A., Rieber, A., Tran, T. A. D., 2015. Economic growth and balance-of payments-constraint in Vietnam. Journal of Post-Keynesian Economics, 38(4), 588-615.

Bagnai, A., Rieber, A., Tran, T. A. D., 2016. Sub-Saharan Africa's growth and South-South trade: A generalised Balance-of-payments constraint analysis. Cambridge Journal of Economics. 40(3), 797-820.

Baldwin, R., 2012. Global supply chains: why they emerged, why they matter, and where they are going. Centre for Economic Policy Research Discussion Papers No.9103. SSRN website https://papers.ssrn.com/sol3/papers.cfm?abstract_id=2153484.

Baumeister, C., Peersman, G., 2013. The role of time-varying price elasticities in accounting for volatility changes in the crude oil market. Journal of Applied Econometrics, 28, 1087-1109.

Bosker, M., Garretsen, H., 2012. Economic geography and economic development in Sub-Saharan Africa. The World Bank Economic Review, 26(3), 443-485. doi:10.1093/wber/lhs001.

Botta, A., 2010. Economic development, structural change and natural resource booms: a structuralist perspective. Metroeconomica, 61(3), 510-539. 
Brenton, P., Newfarmer, R., 2007. Watching more than the discovery channel: export cycles and diversification in development. Policy Research Working Paper No.4302. The World Bank, Washington, D.C.

Cadot, O., Carrère, C., Strauss-Kahn, V., 2011. Export diversification: what's behind the hump? Review of Economics and Statistics, 93, 590-605.

Cadot, O., Carrère, C., Strauss-Kahn, V., 2013. Trade diversification, income, and growth: what do we know? Journal of Economic Surveys, 27 (4), 790-812. doi: 10.1111/j.1467-6419.2011. 00719.x.

Chandra, V., Boccardo, J., Osorio Rodarte, I., 2007. Export diversification and competitiveness in developing countries. World Bank, Washington, D.C., unpublished. http://siteresources.worldbank.org/INTEXPCOMNET/Resources/Chandra,_Export_Diversificati on_and_Competitiveness_in_Developing_Countries.pdf.

Chaney, T., 2008. Distorted gravity: the intensive and extensive margins of international trade. American Economic Review, 98(4), 1707-1721.

Chassem, N. P., 2011. Long-run effects of real exchange rate on the nominal and real trade balance in African Franc zone. Munich Personal RePEc Archive Paper No. 30252. MPRA website https://mpra.ub.uni-muenchen.de/30252/1/.

Chen, W., Nord, R., 2017. A rebalancing act for China and Africa: the effects of China's rebalancing on Sub-Saharan Africa's trade and growth. The African Departmental Paper Series. The African Department, International Monetary Fund, Washington, D.C.

Cimoli, M., Fleitas, S., Porcile, G., 2011. Real exchange rate and the structure of exports. MPRA Paper No. 37846. MPRA website https://mpra.ub.uni-muenchen.de/37846/.

Cimoli, M., Porcile, G., Rovira, S., 2010. Structural convergence and the balance-of-payments constraint: why did Latin America fail to converge. Cambridge Journal of Economics, 34(2), 389411.

Collier, P., Dehn, J., 2001. Aid, shocks, and growth. Policy Research Working Paper No.2688. The World Bank, Washington, D.C.

De la Torre, A., Didier, T., Ize, A., Lederman, D., Schmukler, S. L., 2015. Latin America and the rising South: changing world, changing priorities. Latin America and Caribbean Studies. World Bank, Washington, D.C. https://openknowledge.worldbank.org/ handle/10986/21869.

Diaw, D., Rieber, A., Tran, T. A. D., 2012. International demand spillovers in South-South exports: application to Sub-Saharan Africa and the Developing Asia. Journal of Economic Integration, 27(3), 410-436.

Dornbusch, R., Fischer, S., Samuelson, P. A., 1977. Comparative advantage, trade and payments in a ricardian model with a continuum of goods. American Economic Review, 67, 823-839.

Dosi, G., Pavitt, K., Soete, L., 1990. The economics of technical change and international trade. Brighton, Wheatsheaf and New York: New York University Press.

Easterly, W., Reshef, A., Schwenkenberg, J., 2009. The power of exports. Policy Research Working Paper No. 5081. The World Bank, Washington, D.C.

Evenett, S., Venables, A., 2002. Export growth in developing countries: market entry and bilateral flows. Mimeo, University of Bern.

Feenstra, R., Kee, H. L., 2008. Export variety and country productivity: estimating the monopolistic competition model with endogenous productivity. Journal of International Economics, 74, 500518.

Felipe, J., Kumar, U., Abbon, A., Bacate, M., 2012. Product complexity and economic development. Structural Change and Economic Dynamics, 23(1), 36-68.

Hausmann, R., Hwang, J., Rodrik, D., 2007. What you export matters. Journal of Economic Growth, 12(1), 1-25

Hidalgo, C.A., Klinger, B., Barabasi, A.L., Hausmann, R. , 2007. The product space conditions the development of nations. Science, 317(5837), 482-487.

Hidalgo, C., Hausmann, R., 2009. The building blocks of economic complexity. Proceedings of the National Academy of Sciences of the United States of America 106 (26), 10570-10575.

Imbs, J., Wacziarg, R., 2003. Stages of Diversification. The American Economic Review, 93(1), 63-86. 
International Monetary Fund (IMF), 2014a. Sustaining long-run growth and macroeconomic stability in Low-Income Countries-The role of structural transformation and diversification. IMF Policy Paper. https://www.imf.org/external/np/pp/eng/2014/030514.pdf.

International Monetary Fund (IMF), 2014b. Sustaining long-run growth and macroeconomic stability in Low-Income Countries -- The Role of Structural Transformation and DiversificationBackground Notes. IMF Policy Paper. https://www.imf.org/external/np/pp/ eng/2014/030514a.pdf

International Monetary Fund (IMF), 2015. Regional economic outlook: Sub-Saharan Africa, dealing with the gathering clouds. International Monetary Fund, Washington, D.C.

International Monetary Fund (IMF), 2017. Cluster report - Trade integration in Latin America and The Caribbean. IMF Country Report No. 17/6. International Monetary Fund, Washington, D.C.

Klinger, B., Lederman, D., 2006. Diversification, innovation, and imitation inside the global technology frontier. Policy Research Working Paper No.3872. The World Bank, Washington, D.C.

Koopman, R., Wang, Z., Wei, S.-J., 2014. Tracing value-added and double counting in gross exports. American Economic Review, 104(2), 459-494.

Krugman, R. P., 1979. Increasing returns, monopolistic competition and international trade. Journal of International Economics, 9, 469-479.

Lederman, D., Maloney, W. F., 2006. Natural resources: neither curse nor destiny. The World Bank, Washington, D.C.

Lederman, D., Maloney, W. F., 2012. Does what you export matters? The World Bank, Washington, D.C.

Lederman, D., Olarreaga, M., Perry, G. E., 2009. Latin America's response to China and India: overview of research findings and policy implications, in Lederman, D., Olarreaga, M. and Perry, G. E. (Eds), China's and India's Challenge to Latin America Opportunity or Threat, pp. 3-35, The World Bank, Washington, D.C.

Lin, J. Y., Chang, H. J., 2009. Should Industrial policy in developing countries conform to comparative advantage or defy it? A Debate Between Justin Lin and Ha-Joon Chang. Development Policy Review, 27(5), 483-502.

Mathai, K., Gottlieb, G., Hong, G. H., Jung, S. E., Schmittmann, J., Yu, J., 2016. China's changing trade and implications for the CLMV Economies. The Asia and Pacific Department, International Monetary Fund, Washington, D.C.

McMillan, M. S., Rodrik, D., 2011. Globalization, structural change and productivity growth. National Bureau of Economic Research Working Papers No.17143. NBER website http://www.nber.org/papers/w17143.

McMillan, M., Rodrik, D., Verduzco-Gallo, I., 2014. Globalization, structural change, and productivity growth, with an update on Africa. World Development, 63, 11-32.

Meier, G. M., Seers, D., 1984. Pioneers in development. Oxford University Press.

Melitz, M. J., 2003. The impact of trade on intra-industry reallocations and aggregate industry productivity. Econometrica, 71, 1695-1725.

Naudé, W., Rossouw, R., 2011. Export diversification and economic performance: evidence from Brazil, China, India and South Africa. Economic Change and Restructuring, 44, 99-134.

Olofin, S., Babatunde, M. A., 2007. Estimating price and income elasticities of Sub-Saharan African exports. Paper presented at the 12th Annual Conference on Econometric Modeling for Africa. http://www.africametrics.org/conference-papers.html.

Papageorgiou, C., Spatafora, N., 2012. Economic Diversification in LICs: Stylized facts and macroeconomic implications. IMF Staff Discussion Note, International Monetary Fund.

Papageorgiou, C., Spatafora, N., Wang, K., 2015. Diversification, growth, and volatility in Asia. Policy Reasearch Working Paper No.7380. The World Bank, Washington, D.C.

Parteka, A., 2007. Employment and export specialization patterns versus GDP per capita performance: unifying approach. Working paper No.302. Universita Politecnica delle Marche (I), Dipartimento di Scienze Economiche e Sociali. https://ideas.repec.org/ p/anc/wpaper/302.html. 
Prebisch, R., 1950. The economic development of Latin America and its principal problems. Economic Bulletin for Latin America, 7(1), 1-22.

Prebisch, R., 1959. Commercial policy in the underdeveloped countries. American Economic Review, 49(2), 251-273.

Ricardo, D., 1817. On the principles of political economy and taxation. London John Murray.

Rodrik, D., 2012. Comments on new structural economics by Justin Yifu Lin. World Bank Res Obs, 26(2), 227-229.

Sachs, J. D., Warner, A. M., 1997. Sources of slow growth in African economies. Journal of African Economies, 6(3), 335-376.

Santos-Paulino, A., Thirlwall, A. P., 2004. The impact of trade liberalisation on Exports, imports and the Balance of Payments of Developing Countries. The Economic Journal, 114(493), F50-F72.

Singer, H. W., 1950. The distribution of gains between investing and borrowing countries. American Economic Review, 60, 473-485.

Theil, H., 1972. Statistical decomposition analysis. North Holland.

Thirlwall, A.P., 1979. The Balance of Payments Constraint as an explanation of international growth rate differences. Banca Nazionale di Lavoro, 128, 45-53.

UNCTAD, 2013. Global Value Chains and Development: investment and value-added trade in the global economy. United Nations publication/DAE/2013/1, pp.40.

Vera, L. A., 2006. The Balance-of-Payments constrained growth model: a North-South approach. Journal of Post-Keynesian Economics, 29(1), 67-92.

Wade, R., 1990. Governing the market. Princeton and Oxford: Princeton University Press.

World Bank, 1993. The East Asian miracle: economic growth and public policy. New York, N.Y.: Oxford University Press.

World Bank, 2016. World development indicators. The World Bank, Washington, D.C. 


\section{Appendix A. The Theil index}

We follow the definitions and methods used in Cadot et al. (2011) to calculate the overall, intensive and extensive Theil indices. The Theil index (1972) calculates the dispersion of export shares in terms of products in the total exports. It is given by the following formula:

$$
T=\frac{1}{n} \sum_{k=1}^{n} \frac{x_{k}}{\mu} \ln \left(\frac{x_{k}}{\mu}\right) \text { with } \mu=\frac{1}{n} \sum_{k=1}^{n} x_{k}
$$

Where $n$ is the number of export lines and $x_{k}$ is the export value of product $k$. A relatively high level of the index corresponds to a relative concentration of exports while conversely, a relatively low level of the index reveals a diversified structure of exports. The overall Theil index $T$ is the sum of the "between" component (or the extensive margin) denoted $\mathrm{T}^{\mathrm{B}}$ and the "within" component (or the intensive margin), denoted $\mathrm{T}^{\mathrm{w}}$ :

$$
T=T^{B}+T^{W}
$$

For each country and each year, the Extensive Theil $\mathrm{T}^{\mathrm{B}}$ is calculated by:

$$
T^{B}=\sum_{j=0}^{1} \frac{n_{j}}{n} \frac{\mu_{j}}{\mu} \ln \left(\frac{\mu_{j}}{\mu}\right)
$$

And Intensive Margin or Intensive Theil $\mathrm{T}^{\mathrm{W}}$ :

$$
T^{W}=\sum_{j=0}^{1} \frac{n_{j}}{n} \frac{\mu_{j}}{\mu}\left[\frac{1}{n_{j}} \sum_{k \in j} \frac{x_{k}}{\mu_{j}} \ln \left(\frac{x_{k}}{\mu_{j}}\right)\right]
$$

Where group $1(j=1)$ corresponds to active export lines and the group zero $(j=0)$ are the inactive export lines, $n_{j}$ is the total number of products in each group $j, \mu_{j}$ is the average value of exports in each group and $\left(\mu_{j} / \mu\right)$ is the relative average of exports in each group. 


\section{Appendix B. Countries by region}

For our study, we selected 54 developing countries, which are divided by region into 3 samples. Depending on their income level (gross national income per capita), the developing countries are classified as low income (LI), lower-middle income (LMI) or upper-middle income (UMI) economies, as defined by the World Bank. We chose to use the country classification for the fiscal year 2016.

Table 2: List of Developing Countries

\begin{tabular}{|c|c|c|c|c|c|}
\hline \multicolumn{2}{|l|}{$\begin{array}{l}\text { Developing Asia } \\
\text { (17 countries) }\end{array}$} & \multicolumn{2}{|c|}{$\begin{array}{c}\text { Sub-Saharan Africa } \\
\text { ( } 21 \text { countries) }\end{array}$} & \multicolumn{2}{|l|}{$\begin{array}{l}\text { Latin America } \\
\text { (16 countries) }\end{array}$} \\
\hline Country & Status & Country & Status & Country & Status \\
\hline Bangladesh (BGD) & LMI & Angola (AGO) & UMI & Argentina (ARG) & UMI \\
\hline Bhutan (BTN) & LMI & Burkina Faso (BFA) & LI & Bolivia (BOL) & LMI \\
\hline Cambodia (KHM) & LMI & Cameroon (CMR) & LMI & Brazil (BRA) & UMI \\
\hline China $(\mathrm{CHN})$ & UMI & Congo, Dem. Rep. (ZAR) & $\mathrm{LI}$ & Colombia (COL) & UMI \\
\hline India (IND) & LMI & Congo, Rep. (COG) & LMI & Costa Rica (CRI) & UMI \\
\hline Indonesia (IDN) & LMI & Cote d'Ivoire (CIV) & LMI & Cuba (CUB) & UMI \\
\hline Lao PDR (LAO) & LMI & Ethiopia (ETH) & $\mathrm{LI}$ & Dominican Rep. (DOM) & UMI \\
\hline Malaysia (MYS) & UMI & Ghana (GHA) & LMI & Ecuador (ECU) & UMI \\
\hline Mongolia (MNG) & LMI & Guinea (GIN) & LI & El Salvador (SLV) & LMI \\
\hline Myanmar (MMR) & LMI & Kenya (KEN) & LMI & Guatemala (GTM) & LMI \\
\hline Nepal (NPL) & $\mathrm{LI}$ & Madagascar (MDG) & $\mathrm{LI}$ & Honduras (HND) & LMI \\
\hline Pakistan (PAK) & LMI & Mali (MLI) & LI & Mexico (MEX) & UMI \\
\hline Papua New Guinea (PNG) & LMI & Mozambique (MOZ) & $\mathrm{LI}$ & Panama (PAN) & UMI \\
\hline Philippines (PHL) & LMI & Nigeria (NGA) & LMI & Paraguay (PRY) & UMI \\
\hline Sri Lanka (LKA) & LMI & Senegal (SEN) & LI & Peru (PER) & UMI \\
\hline Thailand (THA) & UMI & South Africa (ZAF) & UMI & Venezuela, RB (VEN) & UMI \\
\hline \multirow[t]{5}{*}{ Vietnam (VNM) } & LMI & Sudan (SDN) & LMI & & \\
\hline & & Tanzania (TZA) & $\mathrm{LI}$ & & \\
\hline & & Uganda (UGA) & LI & & \\
\hline & & Zambia (ZMB) & LMI & & \\
\hline & & Zimbabwe (ZWE) & $\mathrm{LI}$ & & \\
\hline
\end{tabular}

Source: World Bank (World Development Indicators), 2016. 
Appendix C. Export diversification in selected countries over time (1995-2015) Figure 4: Measured by overall Theil index

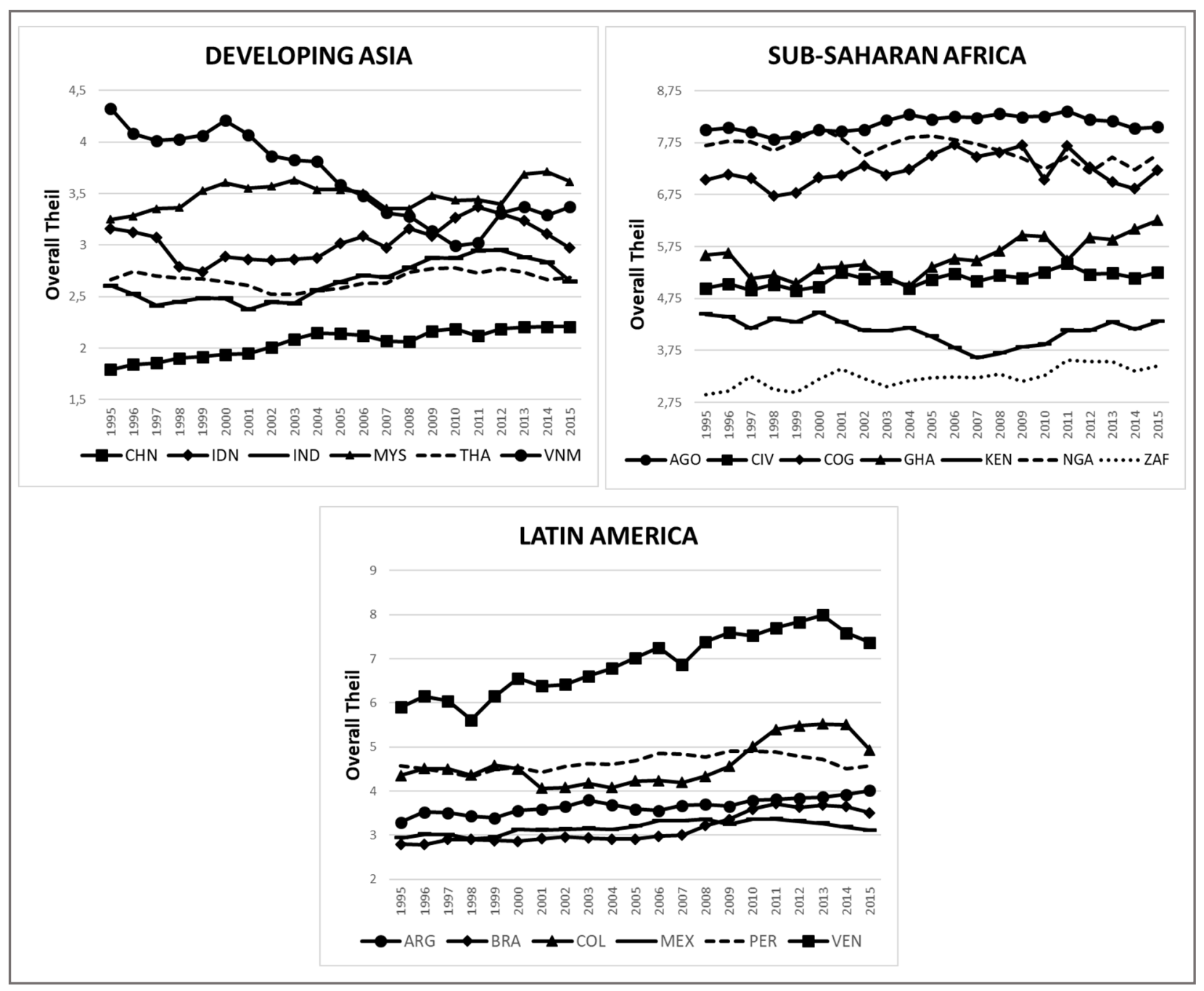

Source: Authors' calculations from BACl database, 2017. 
Figure 5: Measured by extensive and intensive Theil indices

EXTENSIVE MARGIN
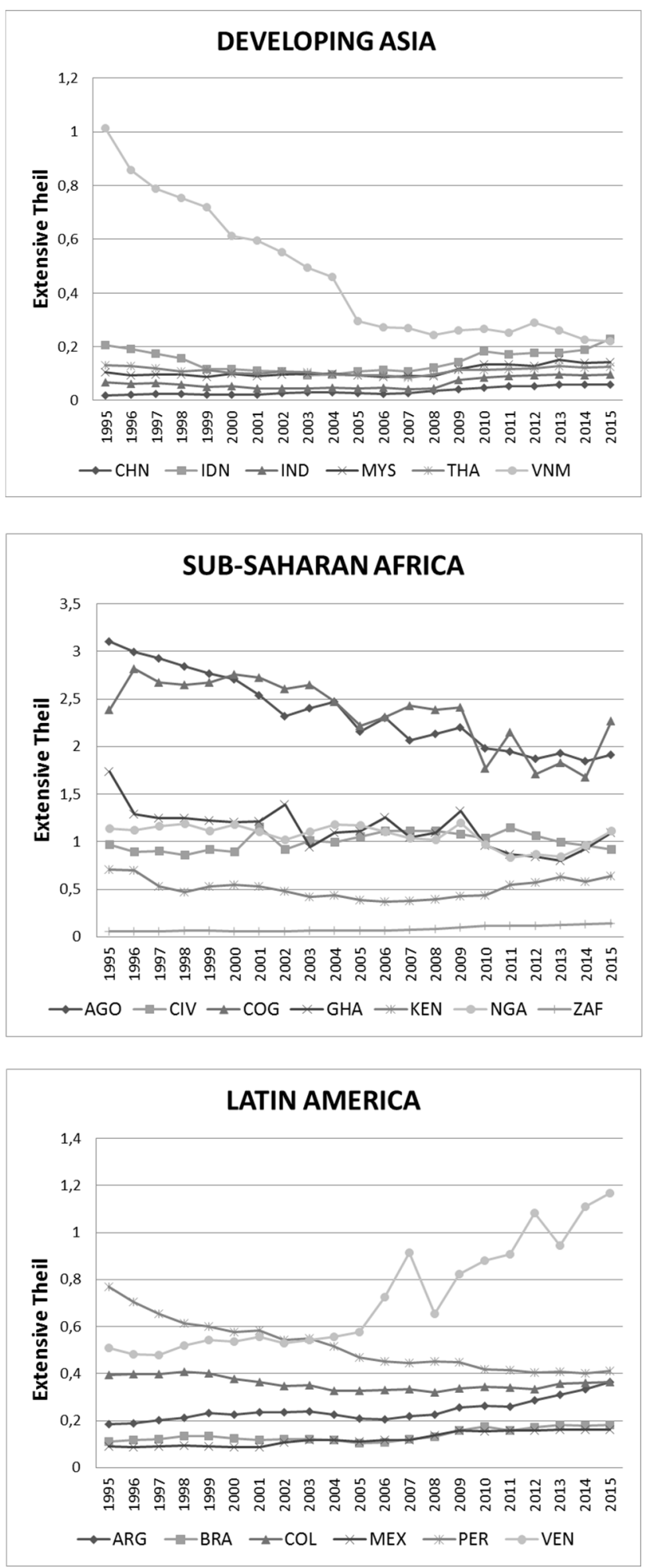

INTENSIVE MARGIN
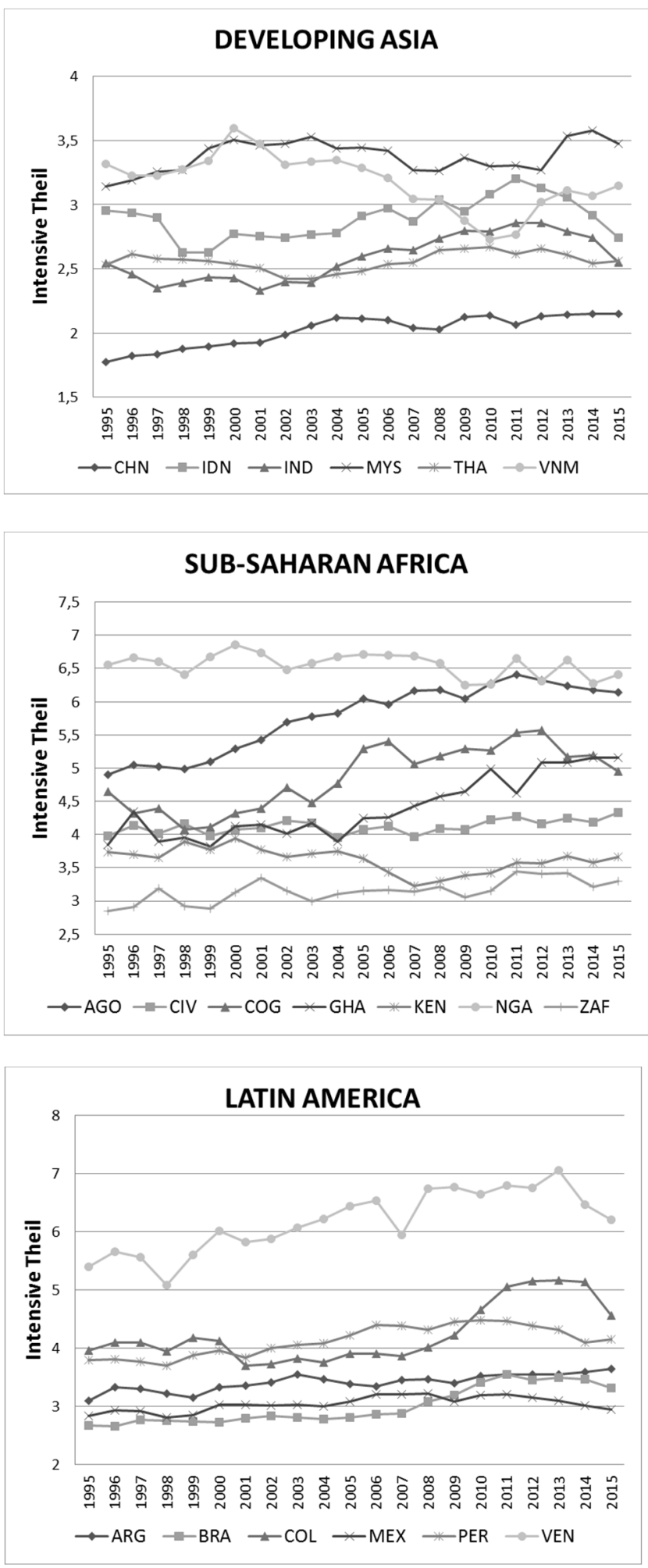

Source: Authors' calculations from BACl database, 2017 
Appendix D. Estimation results: impact of export product diversification in the 3 developing regions

Table 3: Developing Asia

\begin{tabular}{|c|c|c|c|c|c|c|c|}
\hline \multirow[t]{2}{*}{$\begin{array}{l}\text { Explanatory } \\
\text { variables }\end{array}$} & \multicolumn{3}{|c|}{$\begin{array}{l}\text { Exports in Developing Asia } \\
\text { Dependent variable: } \log \text { Exports }\left(\log X_{i t}\right)\end{array}$} & \multirow[t]{2}{*}{$\begin{array}{l}\text { Explanatory } \\
\text { variables }\end{array}$} & \multicolumn{3}{|c|}{$\begin{array}{l}\text { Imports in Developing Asia } \\
\text { Dependent variable: log Imports }\left(\log M_{i t}\right)\end{array}$} \\
\hline & Overall Theil & Extensive Theil & Intensive Theil & & Overall Theil & Extensive Theil & Intensive Theil \\
\hline $\log X_{t-1}$ & $\begin{array}{c}0.592 * * * \\
(0.106)\end{array}$ & $\begin{array}{c}0.789 * * * \\
(0.040)\end{array}$ & $\begin{array}{c}0.557^{* * *} \\
(0.111)\end{array}$ & $\log M_{t-1}$ & $\begin{array}{c}0.555^{* * *} \\
(0.094)\end{array}$ & $\begin{array}{c}0.609 * * * \\
(0.094)\end{array}$ & $\begin{array}{c}0.426 * * * \\
(0.113)\end{array}$ \\
\hline $\log \left(P_{d} / P_{f}\right)_{t}$ & $\begin{array}{l}-0.355^{* *} \\
(0.150)\end{array}$ & $\begin{array}{l}-0.073 \\
(0.058)\end{array}$ & $\begin{array}{c}-0.391 * * * \\
(0.124)\end{array}$ & $\log \left(P_{d} / P_{f}\right)_{t}$ & $\begin{array}{l}-0.209 * * \\
(0.110)\end{array}$ & $\begin{array}{l}-0.179 \\
(0.107)\end{array}$ & $\begin{array}{l}-0.374 * * \\
(0.147)\end{array}$ \\
\hline $\log Z_{t}$ & $\begin{array}{c}1.437^{* * *} \\
(0.477)\end{array}$ & $\begin{array}{c}0.606 * * * \\
(0.188)\end{array}$ & $\begin{array}{c}1.379 * * * \\
(0.483)\end{array}$ & $\log Y_{t}$ & $\begin{array}{c}0.750 * * * \\
(0.155)\end{array}$ & $\begin{array}{c}0.622^{* * *} \\
(0.146)\end{array}$ & $\begin{array}{c}0.797^{* * *} \\
(0.248)\end{array}$ \\
\hline$D I V_{t-1} \log Z_{t}$ & $\begin{array}{c}0.004 \\
(0.002)\end{array}$ & $\begin{array}{c}-0.005 * \\
(0.003)\end{array}$ & $\begin{array}{c}0.007 * * \\
(0.003)\end{array}$ & $D I V_{t-1} \log Y_{t}$ & $\begin{array}{c}0.003 \\
(0.002)\end{array}$ & $\begin{array}{c}-0.011 * * \\
(0.005)\end{array}$ & $\begin{array}{c}0.0122 \\
(0.0094)\end{array}$ \\
\hline Diagnostic statistics & & & & Diagnostic statistics & & & \\
\hline AR (1) & 0.0071 & 0.0023 & 0.0192 & AR (1) & 0.0351 & 0.0234 & 0.0428 \\
\hline$A R(2)$ & 0.243 & 0.581 & 0.251 & $A R(2)$ & 0.212 & 0.241 & 0.157 \\
\hline Hansen Test & 1 & 1 & 1 & Hansen Test & 1 & 1 & 1 \\
\hline F-test & 0 & 0 & 0 & F-test & 0 & 0 & 0 \\
\hline Number of countries & 17 & 17 & 17 & Number of countries & 17 & 17 & 17 \\
\hline Observations & 306 & 306 & 306 & Observations & 306 & 306 & 306 \\
\hline
\end{tabular}

Notes: Dummy variables for latecomer status have been added to take into account the heterogeneity of DA countries. Figures in () are robust standard errors and diagnostic statistics are p-values. $* *, * *$ and $*$ indicate that coefficient is significant at $1 \%, 5 \%$ and $10 \%$ respectively. We perform GMM-difference estimation (Arellano and Bond, 1991) and lags of dependent and independent variables are used as instruments. Results of the tests for AR(1) and AR(2) are the p-values of Arellano and Bond tests for first and second-order autocorrelation in first differences: the null hypothesis of absence of first-order serial correlation AR(1) is rejected and the null hypothesis of zero second-order autocorrelation $\mathrm{AR}(2)$ is not rejected. Hansen statistics are tests of overidentifying restrictions and show that the instruments are valid by not rejecting the null hypothesis. Ftests give $p$-values for overall model fit. 


\section{Table 4: Sub-Saharan Africa}

\begin{tabular}{|c|c|c|c|c|c|c|c|}
\hline \multirow[t]{2}{*}{$\begin{array}{l}\text { Explanatory } \\
\text { variables }\end{array}$} & \multicolumn{3}{|c|}{$\begin{array}{l}\text { Exports in Sub-Saharan Africa } \\
\text { Dependent variable: } \log \text { Exports }\left(\log X_{i t}\right)\end{array}$} & \multirow[t]{2}{*}{$\begin{array}{l}\text { Explanatory } \\
\text { variables }\end{array}$} & \multicolumn{3}{|c|}{$\begin{array}{l}\text { Imports in Sub-Saharan Africa } \\
\text { Dependent variable: Iog Imports }\left(\log M_{i t}\right)\end{array}$} \\
\hline & Overall Theil & Extensive Theil & Intensive Theil & & Overall Theil & Extensive Theil & Intensive Theil \\
\hline $\log X_{t-1}$ & $\begin{array}{c}0.797^{* * *} \\
(0.091)\end{array}$ & $\begin{array}{c}0.628 * * * \\
(0.084)\end{array}$ & $\begin{array}{c}0.668 * * * \\
(0.076)\end{array}$ & $\log M_{t-1}$ & $\begin{array}{r}0.460 * * * \\
(0.083)\end{array}$ & $\begin{array}{l}0.434 * * * \\
(0.080)\end{array}$ & $\begin{array}{l}0.516 * * * \\
(0.123)\end{array}$ \\
\hline $\log \left(P_{d} / P_{f}\right)_{t}$ & $\begin{array}{l}0.013 \\
(0.016)\end{array}$ & $\begin{array}{c}0.002 \\
(0.020)\end{array}$ & $\begin{array}{l}0.006 \\
(0.016)\end{array}$ & $\log \left(P_{d} / P_{f}\right)_{t}$ & $\begin{array}{l}0.060^{* *} \\
(0.024)\end{array}$ & $\begin{array}{c}0.071^{* * *} \\
(0.018)\end{array}$ & $\begin{array}{c}0.057^{* *} \\
(0.023)\end{array}$ \\
\hline $\log Z_{t}$ & $\begin{array}{l}0.359^{*} \\
(0.205)\end{array}$ & $\begin{array}{c}0.742 * * * \\
(0.200)\end{array}$ & $\begin{array}{c}0.693^{* * *} \\
(0.197)\end{array}$ & $\log Y_{t}$ & $\begin{array}{c}0.717^{* * *} \\
(0.138)\end{array}$ & $\begin{array}{c}0.849 * * * \\
(0.155)\end{array}$ & $\begin{array}{c}0.568 * * * \\
(0.160)\end{array}$ \\
\hline$D I V_{t-1} \log Z_{t}$ & $\begin{array}{c}0.001 \\
(0.002)\end{array}$ & $\begin{array}{l}-0.002 \\
(0.002)\end{array}$ & $\begin{array}{l}-0.000 \\
(0.001)\end{array}$ & $D I V_{t-1} \log Y_{t}$ & $\begin{array}{c}0.002 \\
(0.001)\end{array}$ & $\begin{array}{r}0.006 * * \\
(0.003)\end{array}$ & $\begin{array}{l}0.005 \\
(0.003)\end{array}$ \\
\hline Diagnostic statistics & & & & Diagnostic statistics & & & \\
\hline AR (1) & 0.0024 & 0.0017 & 0.0024 & AR (1) & 0.0089 & 0.0118 & 0.0046 \\
\hline $\operatorname{AR}(2)$ & 0.497 & 0.613 & 0.585 & AR (2) & 0.458 & 0.459 & 0.459 \\
\hline Hansen Test & 1 & 1 & 1 & Hansen Test & 1 & 1 & 1 \\
\hline F-test & 0 & 0 & 0 & F-test & 0 & 0 & 0 \\
\hline Number of countries & 21 & 21 & 21 & Number of countries & 21 & 21 & 21 \\
\hline Observations & 378 & 378 & 378 & Observations & 378 & 378 & 378 \\
\hline
\end{tabular}

Notes: Figures in () are robust standard errors and diagnostic statistics are p-values. ${ }^{* * *}, * *$ and $*$ indicate that coefficient is significant at $1 \%, 5 \%$ and $10 \%$ respectively. We perform GMM-difference estimation (Arellano and Bond, 1991) and lags of dependent and independent variables are used as instruments. Results of the tests for AR(1) and $\mathrm{AR}(2)$ are the $\mathrm{p}$-values of Arellano and Bond tests for first and second-order autocorrelation in first differences: the null hypothesis of absence of first-order serial correlation $A R(1)$ is rejected and the null hypothesis of zero second-order autocorrelation $A R(2)$ is not rejected. Hansen statistics are tests of overidentifying restrictions and show that the instruments are valid by not rejecting the null hypothesis. F-tests give $p$-values for overall model fit. 


\section{Table 5: Latin America}

\begin{tabular}{|c|c|c|c|c|c|c|c|}
\hline \multirow[t]{2}{*}{$\begin{array}{l}\text { Explanatory } \\
\text { variables }\end{array}$} & \multicolumn{3}{|c|}{$\begin{array}{l}\text { Exports in Latin America } \\
\text { Dependent variable: } \log \text { Exports }\left(\log X_{i t}\right)\end{array}$} & \multirow[t]{2}{*}{$\begin{array}{l}\text { Explanatory } \\
\text { variables }\end{array}$} & \multicolumn{3}{|c|}{$\begin{array}{l}\text { Imports in Latin America } \\
\text { Dependent variable: } \log \text { Imports }\left(\log M_{i t}\right)\end{array}$} \\
\hline & Overall Theil & Extensive Theil & Intensive Theil & & Overall Theil & Extensive Theil & Intensive Theil \\
\hline $\log X_{t-1}$ & $\begin{array}{c}0.569 * * * \\
(0.123)\end{array}$ & $\begin{array}{c}0.567^{* * *} \\
(0.072)\end{array}$ & $\begin{array}{l}0.460^{* *} \\
(0.182)\end{array}$ & $\log M_{t-1}$ & $\begin{array}{c}0.436 * * * \\
(0.066)\end{array}$ & $\begin{array}{c}0.376 * * * \\
(0.078)\end{array}$ & $\begin{array}{c}0.335^{* * *} \\
(0.087)\end{array}$ \\
\hline $\log \left(P_{d} / P_{f}\right)_{t}$ & $\begin{array}{l}-0.161^{* * *} \\
(0.041)\end{array}$ & $\begin{array}{c}-0.138^{* * *} \\
(0.025)\end{array}$ & $\begin{array}{c}-0.210^{* * *} \\
(0.051)\end{array}$ & $\log \left(P_{d} / P_{f}\right)_{t}$ & $\begin{array}{c}0.042 \\
(0.038)\end{array}$ & $\begin{array}{l}0.104^{* *} \\
(0.046)\end{array}$ & $\begin{array}{l}0.085^{*} \\
(0.043)\end{array}$ \\
\hline $\log Z_{t}$ & $\begin{array}{c}0.759 * * * \\
(0.232)\end{array}$ & $\begin{array}{c}0.723^{* * *} \\
(0.154)\end{array}$ & $\begin{array}{c}0.964 * * * \\
(0.323)\end{array}$ & $\log Y_{t}$ & $\begin{array}{c}0.654^{* * *} \\
(0.115)\end{array}$ & $\begin{array}{c}0.766^{* * *} \\
(0.118)\end{array}$ & $\begin{array}{c}0.768^{* * *} \\
(0.145)\end{array}$ \\
\hline$D I V_{t-1} \log Z_{t}$ & $\begin{array}{l}-0.000 \\
(0.001)\end{array}$ & $\begin{array}{l}-0.005^{*} \\
(0.003)\end{array}$ & $\begin{array}{l}0.000 \\
(0.001)\end{array}$ & $D I V_{t-1} \log Y_{t}$ & $\begin{array}{c}0.003^{* *} \\
(0.001)\end{array}$ & $\begin{array}{l}0.000 \\
(0.005)\end{array}$ & $\begin{array}{l}0.003^{*} \\
(0.002)\end{array}$ \\
\hline Diagnostic statistics & & & & Diagnostic statistics & & & \\
\hline $\operatorname{AR}(1)$ & 0.0725 & 0.0957 & 00891 & $A R(1)$ & 0.0177 & 0.0293 & 0.0294 \\
\hline$A R(2)$ & 0.921 & 0.615 & 0.950 & AR (2) & 0.135 & 0.223 & 0.164 \\
\hline Hansen Test & 1 & 1 & 1 & Hansen Test & 1 & 1 & 1 \\
\hline F-test & 0 & 0 & 0 & F-test & 0 & 0 & 0 \\
\hline Number of countries & 16 & 16 & 16 & Number of countries & 16 & 16 & 16 \\
\hline Observations & 288 & 288 & 288 & Observations & 288 & 288 & 288 \\
\hline
\end{tabular}

Notes: Figures in () are robust standard errors and diagnostic statistics are p-values. ${ }^{* * *},{ }^{* *}$ and ${ }^{*}$ indicate that coefficient is significant at $1 \%, 5 \%$ and $10 \%$ respectively. We perform GMM-difference estimation (Arellano and Bond, 1991) and lags of dependent and independent variables are used as instruments. Results of the tests for AR(1) and $A R(2)$ are the $p$-values of Arellano and Bond tests for first and second-order autocorrelation in first differences: the null hypothesis of absence of first-order serial correlation $A R(1)$ is rejected and the null hypothesis of zero second-order autocorrelation $A R(2)$ is not rejected. Hansen statistics are tests of overidentifying restrictions and show that the instruments are valid by not rejecting the null hypothesis. F-tests give $p$-values for overall model fit. 